\title{
Breakthroughs and challenges of modern developmental biology and reproductive medicine
}

\author{
SIMON FISHEL ${ }^{1}$, ANNA-KATERINA HADJANTONAKIS ${ }^{2}$, BERENIKA PLUSA ${ }^{3}$, LAURA RIENZI ${ }^{4}$, \\ YOJIRO YAMANAKA ${ }^{5}$, ANETA SUWIŃSKA ${ }^{6}$ and ANNA AJDUK*,6

\begin{abstract}
${ }^{1}$ CARE Fertility Group, Nottingham, UK, ${ }^{2}$ Developmental Biology Program, Sloan Kettering Institute, Memorial Sloan Kettering Cancer Center, New York, USA, ${ }^{3}$ Faculty of Biology, Medicine and Health, The University of Manchester, Manchester, UK, ${ }^{4}$ GENERA Centers for Reproductive Medicine, Clinica Valle Giulia, Rome, Italy, ${ }^{5}$ Goodman Cancer Research Centre, McGill
\end{abstract} \\ University, Montreal, Canada, ${ }^{6}$ Department of Embryology, Faculty of Biology, University of Warsaw, Warsaw, Poland
}

\begin{abstract}
In recent decades we have witnessed unprecedented progress in the field of the developmental biology of mammals. Building on $20^{\text {th }}$ century discoveries, we have managed to increase our understanding of the molecular and cellular mechanisms governing early mammalian embryogenesis and link them to other biological questions, such as stem cells, regeneration, cancer, or tissue and organ formation. Consequently, it has also led to a creation of a completely new branch of reproductive medicine, i.e. assisted reproductive technology (ART). In this Special Issue of The International Journal of Developmental Biology (Int. J. Dev. Biol.) we wished to review state-ofthe-art research regarding early mammalian development, from fertilization up to the implantation stage, and discuss its potential meaning for practical applications, including ART. As an introduction to the issue we present a compilation of short essays written by the most renowned scientists in the field, working both in basic and clinical research. The essays are dedicated to the greatest breakthroughs and challenges of $21^{\text {st }}$ century developmental biology and reproductive medicine.
\end{abstract}

KEY WORDS: embryo, fertilization, ART, developmental biology

In recent decades we have witnessed unprecedented progress in the field of the developmental biology of mammals. Building on the $20^{\text {th }}$ century discoveries of Tarkowski, McLaren, Austin, Chang, Yanagimachi and many others, we managed to increase our understanding of molecular and cellular mechanisms governing early mammalian embryogenesis and link them to other biological questions, such as stem cells, regeneration, cancer, or tissue and organ formation. This advancement has also led to a creation of a completely new branch of reproductive medicine: starting with the introduction of the in vitro fertilization protocol by Edwards and Steptoe, the assisted reproduction technology (ART) was born.

In the current issue of the International Journal of Developmental Biology we wished to review state-of-art research regarding early mammalian development, from fertilization up to implantation stage, and discuss its potential meaning for practical applications, including ART. Therefore, we thought that there is no better way to introduce readers to the issue, than to put together a number of short essays written by the most renowned scientist in the field, working both in basic and clinical research. The essays are dedicated to the greatest breakthroughs and challenges of the $21^{\text {st }}$ century developmental biology and reproductive medicine.

The common theme in the essays is appreciation for novel techniques (genetic and 'omic analyses, genetic modification tools, imaging systems, optimization of embryo culture conditions) permitting to deepen and extend the research and improve clinical outcomes. A strong need for interdisciplinary research, combining expertise of biologists, clinicians, physicists, biostatisticians and computational scientists, as well as moving towards non-canonical mammalian models, is yet another motif that emerges in all the essays. And everybody agrees that there are plenty of exciting discoveries in developmental biology and reproductive medicine waiting ahead.

\section{Simon Fishel (CARE Fertility Group, UK)}

Founder and President of CARE Fertility. For many years has been involved in research and teaching at the University of Cambridge and the University of Nottingham. Specializes in fertility treatment.

The $20^{\text {th }}$ century, exactly 40 years ago, saw the realisation of the first birth achieved by extracorporeal fertilisation - for which the Nobel Prize in Physiology or Medicine was awarded in 2010 (re-

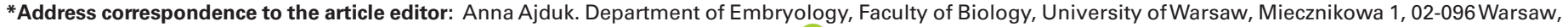
Poland. Tel. +48-225541212. Fax.+48-225541210. E-mail: aajduk@biol.uw.edu.pl - iD https://orcid.org/0000-0002-7262-1370
} 


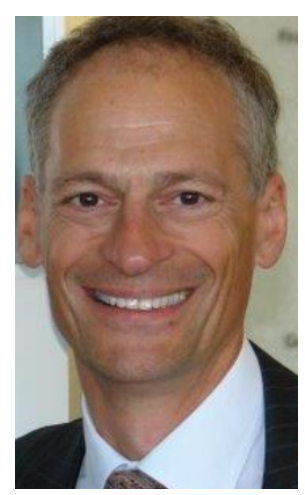

viewed in Fishel, 2018). The end of the $20^{\text {th }}$ century therefore saw enormous progress in human reproduction and developmental biology as a consequence of scientific research and clinical application that has far-reaching implications for the $21^{\text {st }}$ century.

Successful human conception is known to be relatively inefficient, due to a large extent of aneuploidy in embryos, which was known to be prevalent since the early 1980's (Angell etal., 1983). Hence the development of genetic tests to detect aneuploidy became a clinical imperative. Once embryos could be successfully biopsied, it was realised that biopsied cells could reveal the sex and then single gene mutations for clinical use.

The first involvement of genetic screening of embryos some 30 years ago was sexing for a monogenic condition. During the $21^{\text {st }}$ century we have seen the introduction of Next Generation Sequencing (NGS), further developments of this technology for aneuploidy screening, monogenic diagnosis of embryos for hundreds of conditions, pre-conception carrier screening and only recently the prospect of screening human embryos for polygenic conditions has become reality (Lello et al., 2018; www.genomicprediction.com). The combination of embryology technologies and genetics has seen the introduction of 'pronuclear transfer' for mtDNA cytopathies, and the so-called three-parent DNA children (Zhang et al., 2016). DNA detection for embryo assessment still requires an invasive cell removal, but more recently non-invasive and high-throughput assays have been developed (Liu etal., 2017). CRISPR-Cas9 research has been reported successfully to eliminate a whole chromosome raising the prospect of this technology being used for the correction of genetic and chromosome anomalies in embryos rather than their disposal (Zuo et al., 2017).

The $21^{\text {st }}$ century has seen the introduction of 'embryoscopy' into clinical IVF practice - the use of closed incubation systems with integrated microscopy for time-lapse imaging. This not only opened a window on cleavage anomalies that hitherto were unrecognised, but also permitted the use of morphokinetic algorithms for objective embryo selection. Although yet to be adopted completely, it is likely to be heralded as breakthrough technology for understanding human preimplantation embryo in vitro cleavage, and embryo selection for clinical IVF (Campbell and Fishel, 2016; Pribenszky et al., 2017; Fishel et al., 2018). Increasingly we shall see these technical advances in time-lapse imaging, genetic, epigenetic and chromosomal analyses of whole human embryos, and also the advent of 'artificial embryos' greatly improve our understanding of early human embryogenesis at the cell interactive and single, subcellular levels (Carbone et al., 2015; Deglincerti et al., 2016; Shahbazi et al., 2016).

The introduction of vitrification for successful egg freezing has created opportunities for a whole group of patients; particularly for fertility preservation for cancer patients and those with benign disease. It also opens the opportunity for mothers of girls with galactosaemia to preserve eggs for their daughters, as well as empowering all women to preserve fertility for personal, non-medical reasons. Further still, the advent of success ovarian tissue cryopreservation and transplantation may not only provide for fertility preservation, it may become an important health opportunity for naturally postponing the menopause in the aging population (Don- nez and Dolmans, 2017; Amorim et al., 2018).

Perhaps amongst the most intriguing advances of this century is the development of 'artificial gametes', developed from progenitor somatic cells. Live births have already been achieved in animals from a variety of antecedent cells, but in humans, apart from the social and ethical implications the safety and efficacy of such cells remains to be established (reviewed in Hendriks et al., 2015).

Finally, with all the remarkable developments of the $21^{\text {st }}$ century, many of which will undoubtedly continue to bring improvements to human health and a deeper understanding of human conception and developmental biology, possible one of the most remarkable changes has been the use of these technologies for the first time in human history to redefine family life and human procreation (Imrie et al., 2018).

\section{Anna-Katerina Hadjantonakis (Developmental Biology Pro- gram, Sloan Kettering Institute, Memorial Sloan Kettering Can- cer Center, US) \\ Member of the Sloan Kettering Institute, of the Memorial Sloan Kettering Cancer Center, and a Professor at Cornell Uni- versity, New York City, USA. Specializes in pluripotency, cell lineage commitment, tissue patterning, and morphogenesis in mammalian embryos and in vitro stem} cell models.

Embryonic development; what it achieves, and the accuracy with which it is accomplished, is astonishing. Understanding development not only explains how embryos form and tissues are sculpted, but is the benchmark against which we can determine what goes wrong in pathological conditions, such as congenital malformations or cancer. Understanding development underpins any endeavor to repair or replace damaged tissues.

An overarching goal of developmental biology is to glean an understanding of how cells collectively, reproducibly and robustly make embryos (or tissues) of the correct size, and within the correct time-frame. One fundamental behavior that has recently been increasingly appreciated is that cells usually make their individual fate decisions asynchronously within the populations they comprise. We seek to understand how signaling and gene activities interface to define cell states and identities, and how acquisition of an identity is coordinated with cellular organization in emergent tissues.

Rather than looking at a single gene, gene family or signaling pathway of interest, in diverse contexts, an approach prevalent in the late $20^{\text {th }}$ century, there has been a shift to tissue-focused investigations. As we near the end of the first quarter of the $21^{\text {st }}$ century, our qualitative descriptions of old are being replaced by quantitative and dynamic understandings. Moving forward we will traverse scales; from elucidating molecular circuits and determining how they impact cellular states, to cells and understanding how their behaviors impact tissue-level architectures.

From the experimental embryology of the $19^{\text {th }}$, and molecular embryology of the late $20^{\text {th }}$ century, comes the advent of organoid biology, and the ability to generate size-appropriate synthetic embryo-like structures in vitro through the reconstitution of, oftentimes, embryo-derived stem cells. These approaches have some way to go, but one can expect their efficiency to improve, which coupled with their scalability, makes the prospect of synthetic mammalian 
embryos something to anticipate and consider.

Over the past decade a suite of technical innovations has propelled what we can do experimentally. Our methodological toolkit encompasses improvements in the ex utero culture of embryos (or tissues); with better efficiencies and for longer periods of time. This is coupled with the ever-evolving ability to image molecules in cells, and cells in embryos; at increasing temporal, spatial and spectral resolutions. These approaches are complemented by the recent feasibility of precision genomic perturbations, as well as the increasing application of 'omics approaches at the level of single cells. There is an increasing cognizance of the importance of mechanics; the acquisition of biophysical measurements, and consequences of perturbations.

A key challenge moving forward will be to formulate the right questions to ask, and the best system to frame them in. Studies will increasingly be run in parallel in embryos and in synthetic in vitro systems, some of them reductionist. In classical mammalian models such as the mouse, and by extension in human, as well as taking in details from non-classical models. The future is collaborative; an unbiased informed and holistic understanding of embryonic development will only arise through the integration of multiple types of data, by individuals having diverse expertise and perspectives.

Berenika Plusa (Division of Developmental Biology and Medicine, The University of Manchester, UK) Group leader at The University of Manchester, UK. Specializes in preimplantation embryonic development.

The notion that development is a one-way process, during which cells inevitably lose their developmental potential, was successfully contested in the middle of the last century by John Gurdon, who demonstrated that a differentiated, somatic nucleus could

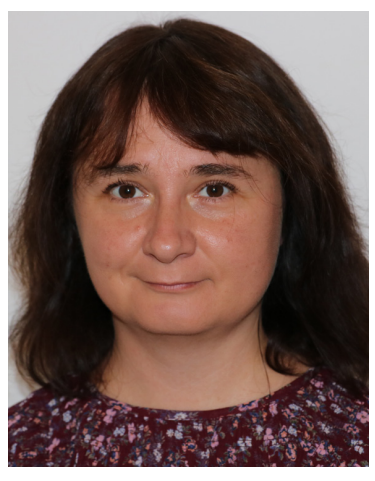
be re-programmed by the cytoplasm of the egg and could drive the embryonic development, regaining the ability to give rise to the various cell types (Gurdon, 1962). At the beginning of $21^{\text {st }}$ century, Kazutoshi Takahashi and Shinya Yamanaka followed Gurdon's pioneering work and demonstrated that mouse fibroblasts can be reprogrammed into the pluripotent cell type - induced pluripotent stem cells (iPS cells), using a combination of only four transcription factors (Takahashi and Yamanaka, 2006). Subsequent generation of human iPS cells (Takahashi et al., 2007) opened entirely new avenues for regenerative medicine and patient-specific therapies. For their discoveries, Gurdon and Yamanaka were awarded the 2012 Nobel Prize in Physiology or Medicine.

Somatic cell reprogramming and iPS technology represent a huge step forward towards the generation of patient-specific cell lines - and potentially whole organs - for replacement therapies. However, to assure safety and reproducibility of the regenerative medicine techniques, the detailed knowledge and understanding of the normal development processes is of the utmost importance. To create complex structures, like a heart or a liver, we need a detailed $4 \mathrm{D}$ roadmap that explains how the cells that constitute given tissue or organ specify and position themselves in their appropriate place, how the functional connections are established between different cell types and cell lineages, and finally how the cells deposit and interact with extracellular matrix components. Formation of an adult organism from a fertilized zygote is a journey with many critical steps and potential roadblocks. Developmental biology provides tools and intellectual paradigm to facilitate understanding of the processes that govern lineage and organ formation. In that sense, developmental biology is still the science of the future.

Looking for stereotypical behavior in flexible, self-organising environment is a very challenging task. Quantification of a variable cell dynamics (cell origin, physical properties, division rate, migration speed and directionality, description of cell dynamic neighborhood, etc.) across different tissues and cell lineages within the developing organism is an important step towards creation of the "digital map" of the lineage and organ development. This needs to be combined with the further understanding of how physical interactions between different parts of the embryo/organs can shape developmental processes. Importantly, combining and comparing digitalized information from multiple embryos/foetuses per stage/ developmental process/developmental period is necessary to account for the high embryo-to-embryo variability - an intrinsic feature of self-organising systems with high plasticity. Data from multiple embryos can then be averaged and used to create a very detailed map of the predicted cell behavior within specific developmental periods. This in turn, can be used to create much more accurate models of developmental processes, as was recently demonstrated by Philipp J. Keller's lab (McDole et al., 2018). Similar "digital organism" maps would be created for mutant embryos, where the function of the gene (or sets of genes) was perturbed in order to understand the origin of pathological processes.

Construction of new models that incorporate both biochemical and physical interaction between different cell lines, organs or embryo components is necessary to further our understanding of the developmental processes. This might not be possible without forging the successful collaborations between developmental biologists, computational scientists, physicists, statisticians, modelers etc. Formation of such intra-disciplinary teams may be an absolute necessity for the developmental biology of the $21^{\text {st }}$ century.

\section{Laura Rienzi ${ }^{\#}$ (Clinica Valle Giulia,} g.en.e.r.a. centers for reproductive medicine, Italy)

Senior Clinical Embryologist, Laboratory Director at the GENERACentres for Reproductive Medicine, Italy, Adjunct Professor of Biotechnology in Assisted Reproduction, Faculty of Biology at the University of Urbino, Italy. Specializes in in vitro fertilization procedures, cryopreservation and quality assessment of gametes and embryos.

"The essay was prepared in collaboration with D. Cimadomo and FM. Ubaldi (Clinica Valle Giulia, g.en.e.r.a. centers for reproductive medicine, Rome, Italy), and S. Alfano and E Alviggi (Clinica Ruesch, g.en.e.r.a. centers for reproductive medicine, Naples, Italy).

IVF is among the fastest developing fields of medicine. Thanks to the pioneering work of Steptoe and Edwards and the courage of their first patients (Edwards, 1981), nowadays millions of infertile couples worldwide might benefit from assisted reproduction technologies. An intensive research activity in this field keeps 


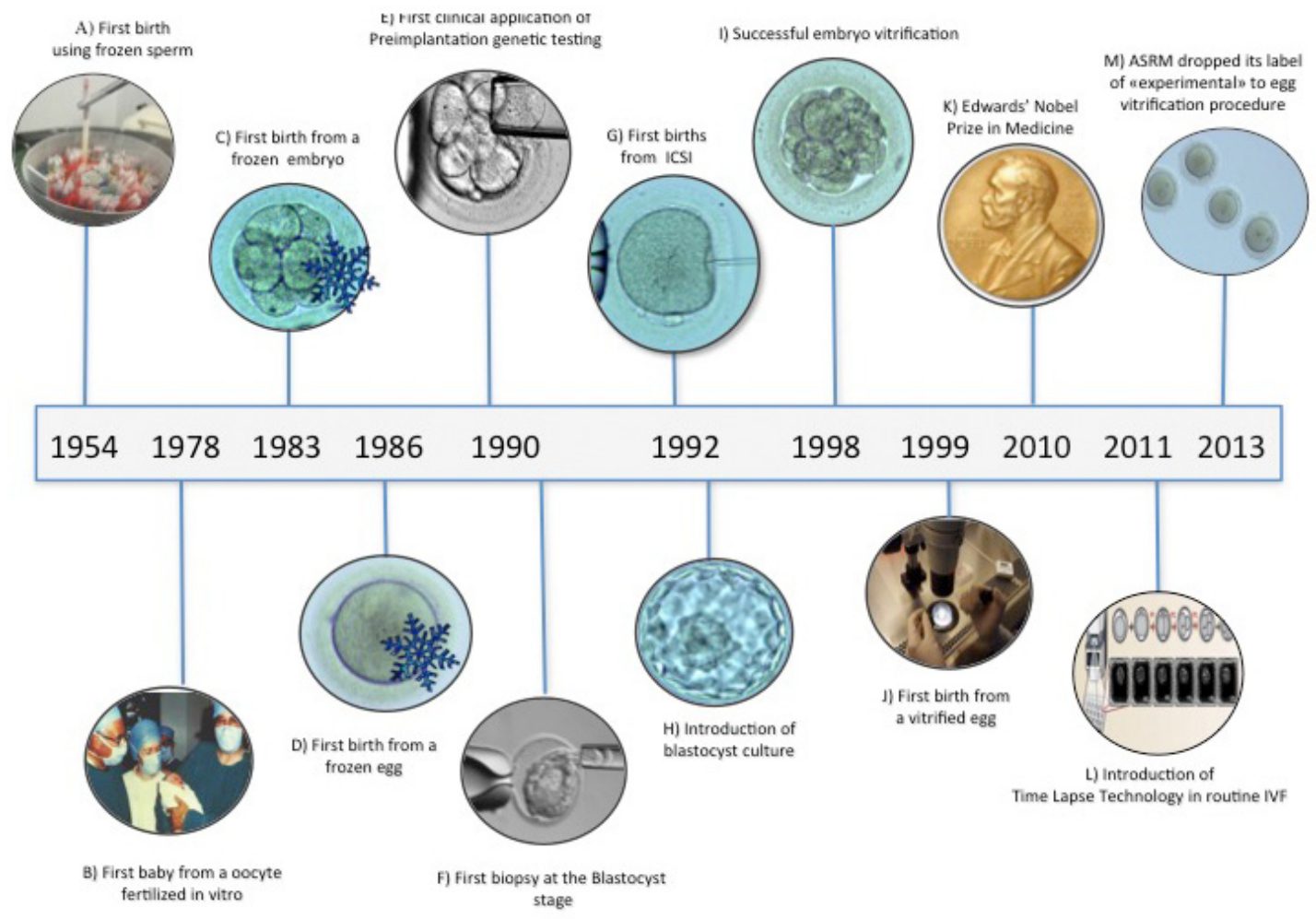

Fig. 1. Timeline of the main achievements of assisted reproductive technology (ART) since its introduction. (A) Bunge et al., 1954; (B) Edwards, 1981; (C) Trounson and Mohr, 1983; (D) Chen, 1986; (E) Handyside et al., 1990; (F) Dokras et al., 1990; (G) Palermo et al., 1992; (H) Menezo et al., 1992; (I) Mukaida et al., 1998; (J) Kuleshova et al., 1999; (L) Meseguer et al., 2011; (M) Practice Committees of American Society for Reproductive Medicine (ASRM); Society for Assisted Reproductive Technology, 2013.

modifying the present and shaping the future approaches and strategies (Fig. 1).

The introduction of cryopreservation represented a gamechanger in IVF. Even if slow-freezing led to substantial improvements, vitrification is a real milestone, which allowed embryologists worldwide to boost oocyte/embryo cryo-survival rates (Rienzi et al., 2017). The optimization and the widespread application of cryopreservation in IVF largely increased also clinical possibilities including: i) the systematic application of an elective singleembryo-transfer policy (Pandian et al., 2013); ii) the possibility to perform blastocyst biopsy and complex time-consuming genetic testing (PGT) (Scott et al., 2013; Chen et al., 2015; Dahdouh et al., 2015); iii) the application of cycle segmentation and freeze-all policy (Devroey et al., 2011; Evans et al., 2014); iv) and the possibility to perform fertility preservation via egg banking for women wishing to postpone their desire of motherhood for either medical (e.g. cancer, endometriosis) or social issues (Cobo et al., 2016; Gunnala and Schattman, 2017).

Several invasive and non-invasive strategies have also recently been proposed to improve embryo selection and encourage SET also in advanced maternal age patients (Gardner et al., 2015), thereby decreasing the risk for multiple pregnancies and their related obstetrical and perinatal consequences (Forman et al., 2013; 2014). The goal of embryo selection is indeed to recognize the most competent embryo(s) within a cohort produced by a couple during IVF, namely the one(s) with the highest chance of resulting in the birth of a healthy child. Recently, time-lapse microscopy and single step culture media suitable for embryos up to blastocyst stage converged into the creation of incubators guaranteeing undisturbed in vitro culture. Such technology enhanced the conventional morphological assessments by involving the detection of several dynamic phenomena and criteria that could be useful to select/ deselect the embryo(s) to transfer without the need to extract the embryos from the incubator during observations. Nevertheless, to date, it mainly represents an ideal incubation system rather than a tool to conduct embryo selection (Kaser and Racowsky, 2014). The most promising data to predict embryo implantation potential has been derived from the advances in genetic testing (Chen et al., 2015; Dahdouh et al., 2015). This strategy, that combines blastocyst culture, trophectoderm biopsy and vitrification needs a high-standard laboratory and highly-trained embryologists and even though has an incredible potential, is still very expensive and not accessible to all.

Many scientists have focused their research upon the biology of human preimplantation embryos and the definition of the blastocystendometrial dialogue, aiming at unveiling its dynamics and some putative biomarkers of competence via '-omic' approaches (genomics, transcriptomics, proteomics etc. (Gardner et al., 2015; Gardner and Balaban, 2016)) applied to the investigation of non-invasive sources of oocyte/embryonic biological material (cumulus cells, follicular fluids, spent culture media, etc). Interesting perspectives may indeed derive from ground-breaking studies conducted in this field, especially through multidisciplinary approaches (e.g. stem cell research, microfluidics, automation) (Meseguer et al., 2012; Woods and Tilly, 2015; Horan and Williams, 2017; Silvestris et al., 2018).

The success of IVF must be grounded on cumulative-live-birth- 
rate perintention-to-treat (Maheshwari et al., 2015) and, via encompassing gynecological, embryological, psychological, genetic and social aspects, envision a personalized treatment for each couple. The future in IVF is yet to come with unpredictable avant-gardes.

Yojiro Yamanaka (Rosalind and Morris Goodman Cancer Research Centre, Department of Human Genetics, McGill University, Canada) Associate Professor at the McGill University, Canada. Specializes in epithelial morphogenesis in early mammalian development and embryonic stem cells.

Remarkable progress has been made in understanding mammalian preimplantation development and reproduction. Many basic studies performed in laboratory animals, predominantly mice, have been translated

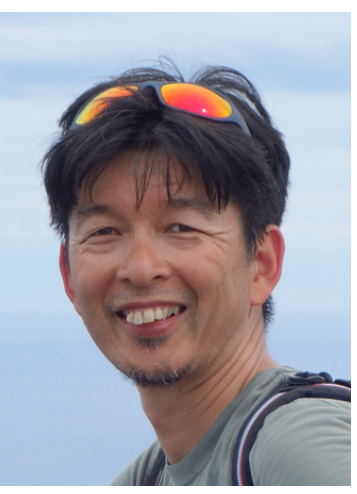
to other mammalian species, including humans. The development of novel experimental techniques to study single cells over the last decade has provided the opportunities for direct comparison between various mammalian species at the molecular and cellular levels. As expected, there are many evolutionarily conserved molecular players and mechanisms, but we have also begun to recognize the differences between mammalian species. As a mouse developmental biologist, I have been fascinated (with a slight disappointment ... ) to learn the developmental differences between mice and other mammals.

On the other hand, interestingly, all mammalian preimplantation development follows a remarkably similar process: early cleavages, compaction, formation of a morula and then a blastocyst. This common process appears to be the base of plasticity and tolerance against experimental insults in mammalian development. The self-organizing ability from compaction to blastocyst formation, driven by the biophysical properties of individual cells, has to be tightly linked with the regulation of gene expression to control lineage specification. We are still far from a full understanding of the molecular mechanisms behind them.

Looking forward, what will be the essential breakthroughs and challenges in the $21^{\text {st }}$ century? To be honest, who knows. Who could have envisioned smartphones, iPSCs and other current inventions 30 years ago? However, since I accepted the editor's invitation, I would like to raise three of them for the next 10-30 years. 1. Understanding development --- molecular and cellular bases of totipotency: I expect that the essence of totipotency, the process of how an egg develops into an organism will be revealed. We might be able to recreate totipotency solely from in vitro cultured cells. 2. Innovation in Assisted Reproductive Technology (humans and livestock) --- selection of good embryos and improving the embryo quality. Currently, morphogeometric and morphokinetic analyses are used to assess the quality of an embryo that potentially implants and develops to term. But what is "the quality"? These experience-based selections should be interpreted at the molecular and cellular levels. This knowledge will help improving not only the selection but developing strategies to increase the quality. 3. Understanding mammalian evolution in placentation and polyembryony. It is interesting to recognize differences in early development and reproduction in mammalian species. Particularly, I am fascinated by variations in placentation and unique polyembryony in nine-banded armadillo. I expect that non-traditional lab animal studies will bring new prospects in the field of development and reproduction.

\section{References}

AMORIM CA,, LEONELECR, AFIFIY, COOMARASAMYA, FISHELS (2018) Cryostorage and retransplantation of ovarian tissue as an infertility treatment. Best Pract Res Clin Endocrinol Metab DOI: 10.1016/j.beem.2018.09.002

ANGELL RR, AITKEN RJ, VAN LOOK PF, LUMSDEN MA and TEMPLETON AA (1983) Chromosome abnormalities in human embryos after in vitro fertilization. Nature 303: 336-338.

BUNGE RG, KEETTEL WC and SHERMAN JK (1954) Clinical use of frozen semen: report of four cases. Fertil Steril 5: 520-529.

CAMPBELL A and FISHEL S, Eds. (2016) Atlas of Time-Lapse of Embryology. CRC Press.

CARBONE L and CHAVEZ SL (2015) Mammalian pre-implantation chromosomal instability: species comparison, evolutionary considerations, and pathological correlations. Syst Biol Reprod Med 61: 321-335.

CHEN C (1986) Pregnancy after human oocyte cryopreservation. Lancet 1: 884-886.

CHEN M, WEI S, HU J and QUAN S (2015) Can Comprehensive Chromosome Screening Technology Improve IVF/ICSI Outcomes? A Meta-Analysis. PLoS One 10: e0140779.

COBO A, GARCÍA-VELASCO JA, COELLO A, DOMINGO J, PELLICER A and REMOHÍ J (2016) Oocyte vitrification as an efficient option for elective fertility preservation. Fertil Steril 105: 755-764 e8.

DAHDOUH EM, BALAYLA J and GARCIA-VELASCO JA (2015) Comprehensive chromosome screening improves embryo selection: a meta-analysis. Fertil Steril 104: 1503-1512.

DEGLINCERTI A, CROFT GF, PIETILA LN, ZERNICKA-GOETZ M, SIGGIA ED and BRIVANLOU AH (2016) Self-organization of the in vitro attached human embryo. Nature 533: 251-254

DEVROEY P, POLYZOS NP, and BLOCKEEL C (2011) An OHSS-Free Clinic by segmentation of IVF treatment. Hum Reprod 26: p. 2593-2597.

DOKRAS A, SARGENT IL, ROSS C, GARDNER RL and BARLOW DH (1990) Trophectoderm biopsy in human blastocysts. Hum Reprod 5: 821-825.

DONNEZ J and DOLMANS MM (2017) Fertility Preservation in Women. N Engl J Med 377: 1657-1665.

EDWARDS RG (1981) Test-tube babies. Nature 293: 253-256.

EVANS J, HANNAN NJ, EDGELL TA, VOLLENHOVEN BJ, LUTJEN PJ, OSIANLIS T, SALAMONSEN LA and ROMBAUTS LJ (2014) Fresh versus frozen embryo transfer: backing clinical decisions with scientific and clinical evidence. Hum Reprod Update 20: 808-821.

FISHEL S (2018) First in vitro fertilization baby -this is how it happened. Fertil Steril 110: 5-11.

FISHELS, CAMPBELLA, MONTGOMERYS, SMITHR, NICE L, DUFFYS, JENNERL et al., (2018) Time-lapse imaging algorithms rank human preimplantation embryos according to the probability of live birth. Reprod Biomed Online 37: 304-313.

FORMAN EJ, HONG KH, FERRY KM, TAO X, TAYLOR D, LEVY B, TREFF NR and SCOTT RT JR (2013) In vitro fertilization with single euploid blastocyst transfer: a randomized controlled trial. Fertil Steril 100: 100-107 e1.

FORMAN EJ, HONG KH, FRANASIAK JM and SCOTT RT JR (2014) Obstetrical and neonatal outcomes from the BEST Trial: single embryo transfer with aneuploidy screening improves outcomes after in vitro fertilization without compromising delivery rates. Am J Obstet Gynecol 210: 157 e1-6.

GARDNER DK and BALABAN B (2016) Assessment of human embryo development using morphological criteria in an era of time-lapse, algorithms and 'OMICS': is looking good still important? Mol Hum Reprod 22: 704-718.

GARDNER DK, MESEGUER M, RUBIO C and TREFF NR (2015) Diagnosis of human preimplantation embryo viability. Hum Reprod Update 21: 727-747.

GUNNALA V and SCHATTMAN G (2017) Oocyte vitrification for elective fertility preservation: the past, present, and future. Curr Opin Obstet Gynecol 29: 59-63. 


\section{S. Fishel et al.}

GURDON JB (1962) The developmental capacity of nuclei taken from intestinal epithelium cells of feeding tadpoles. J Embryol Exp Morphol 10: 622-640.

HANDYSIDE AH, KONTOGIANNI EH, HARDY K and WINSTON RM (1990) Pregnancies from biopsied human preimplantation embryos sexed by Y-specific DNA amplification. Nature 344: 768-770.

HENDRIKS S, DANCET EA, VAN PELT AM, HAMER G and REPPING S (2015) Artificial gametes: a systematic review of biological progress towards clinical application. Hum Reprod Update 21: 285-296.

HORAN CJ and WILLIAMS SA (2017) Oocyte stem cells: fact or fantasy? Reproduction 154: R23-R35.

IMRIE S, JADVA V, FISHEL S and GOLOMBOK S (2018) Families Created by Egg Donation: Parent-Child Relationship Quality in Infancy. Child Dev (In press, DOI: 10.1111/cdev.13124)

KASER DJ and RACOWSKY C (2014) Clinical outcomes following selection of human preimplantation embryos with time-lapse monitoring: a systematic review. Hum Reprod Update 20: 617-631.

KULESHOVAL, GIANAROLI L, MAGLI C, FERRARETTIA and TROUNSONA(1999) Birth following vitrification of a small number of human oocytes: case report. Hum Reprod 14: 3077-3079.

LELLO L, AVERY SG, TELLIER L, VAZQUEZAI, DE LOS CAMPOS G and HSU SDH (2018) Accurate Genomic Prediction of Human Height. Genetics 210: 477-497.

LIU W, LIU J, DU H, LING J, SUN X and CHEN D (2017) Non-invasive pre-implantation aneuploidy screening and diagnosis of beta thalassemia IVSII654 mutation using spent embryo culture medium. Ann Med 9: 319-328.

MAHESHWARI A, MCLERNON D and BHATTACHARYA S (2015) Cumulative live birth rate: time for a consensus? Hum Reprod 30: 2703-2707.

MCDOLEK, GUIGNARD L,AMATF, BERGERA, MALANDAING, ROYERLA, TURAGA SC, BRANSON K and KELLER PJ (2018) In Toto Imaging and Reconstruction of Post-Implantation Mouse Development at the Single-Cell Level. Cell175: 859-876.

MÉNÉZO Y, NICOLLET B, HERBAUT N and ANDRÉ D (1992) Freezing cocultured human blastocysts. Fertil Steril 58: 977-980.

MESEGUER M, HERRERO J, TEJERAA, HILLIGSøE KM, RAMSING NB and REMOHÍ J (2011) The use of morphokinetics as a predictor of embryo implantation. Hum Reprod 26: 2658-2671.

MESEGUER M, KRUHNE U and LAURSEN S (2012) Full in vitrofertilization laboratory mechanization: toward robotic assisted reproduction? Fertil Steril 97: 1277-1286.

MUKAIDA T, WADA S, TAKAHASHI K, PEDRO PB, AN TZ and KASAI M (1998) Vitrification of human embryos based on the assessment of suitable conditions for 8-cell mouse embryos. Hum Reprod 13: 2874-2879.

PALERMO G, JORIS H, DEVROEY P and VAN STEIRTEGHEM AC (1992) Pregnancies after intracytoplasmic injection of single spermatozoon into an oocyte. Lancet 340: 17-18.

PANDIAN Z, MARJORIBANKS J, OZTURK O, SEROUR G and BHATTACHARYA $S$ (2013) Number of embryos for transfer following in vitro fertilisation or intracytoplasmic sperm injection. Cochrane Database Syst Rev CD003416.

PRIBENSZKY C, NILSELID A-M and MONTAG M (2017) Time-lapse culture with morphokinetic embryo selection improves pregnancy and live birth chances and reduces early pregnancy loss: a meta-analysis. Reprod Biomed Online 35:511-520.

RIENZI L, GRACIA C, MAGGIULLI R, LABARBERA AR, KASER DJ, UBALDI FM VANDERPOEL S and RACOWSKY C (2017) Oocyte, embryo and blastocyst cryopreservation in ART: systematic review and meta-analysis comparing slowfreezing versus vitrification to produce evidence for the development of global guidance. Hum Reprod Update 23: 139-155.

SCOTTRT JR, UPHAM KM, FORMAN EJ, ZHAO T and TREFF NR (2013) Cleavagestage biopsy significantly impairs human embryonic implantation potential while blastocyst biopsy does not: a randomized and paired clinical trial. Fertil Steril 100: $624-630$

SHAHBAZIMN, JEDRUSIKA, VUORISTOS, RECHER G, HUPALOWSKAA, BOLTON V, FOGARTY NME, et al., (2016) Self-organization of the human embryo in the absence of maternal tissues. Nat Cell Biol 18: 700-708.

SILVESTRISE, CAFFORIOP, D'ORONZOS, FELICIC, SILVESTRIS F and LOVERRO $\mathrm{G}$ (2018) In vitro differentiation of human oocyte-like cells from oogonial stem cells: single-cell isolation and molecular characterization. Hum Reprod 33: 464-473.

TAKAHASHI K, TANABE K, OHNUKI M, NARITA M, ICHISAKA T, TOMODA K and YAMANAKA S (2007) Induction of pluripotent stem cells from adult human fibroblasts by defined factors. Cell 131: 861-872.

TAKAHASHIK and YAMANAKAS (2006) Induction of pluripotent stem cells from mouse embryonic and adult fibroblast cultures by defined factors. Cell 126: 663-676.

TROUNSON A and MOHR L (1983) Human pregnancy following cryopreservation, thawing and transfer of an eight-cell embryo. Nature 305: 707-709.

WOODS DC and TILLYJL(2015) Autologous Germline Mitochondrial Energy Transfer (AUGMENT) in Human Assisted Reproduction. Semin Reprod Med 33: 410-421.

ZHANG J, ZHUANG G, ZENG Y, GRIFO J, ACOST C, SHU Y and LIU H (2016) Pregnancy derived from human zygote pronuclear transfer in a patient who had arrested embryos after IVF. Reprod Biomed Online 33: 529-533.

ZUO E, XIAONA HUO X, YAO X, HU X, SUN Y, YIN J, HE B, WANG X et al., (2017) CRISPR/Cas9-mediated targeted chromosome elimination. Genome Biol 18:224 


\section{Further Related Reading, published previously in the Int. J. Dev. Biol.}

Decidua and implantation of the embryo from a historical perspective Ivan Damjanov

Int. J. Dev. Biol. (2014) 58: 75-78

https://doi.org/10.1387/ijdb.140075id

From testis to teratomas: a brief history of male germ cells in mammals

Massimo De Felici and Susanna Dolci

Int. J. Dev. Biol. (2013) 57: 115-121

https://doi.org/10.1387/ijdb.130069md

Above the borderland between normal and neoplastic development

Juan Aréchaga and Ivan Damjanov

Int. J. Dev. Biol. (2012) 56: 939-948

https://doi.org/10.1387/ijdb.120255ja

Reprogramming cell fate: a scientific journey from viral enhancers to the master gene regulator Oct4 - an interview with Hans R. Schöler

Michele Boiani

Int. J. Dev. Biol. (2010) 54: 1685-1695

https://doi.org/10.1387/ijdb.103248mb

Some historical aspects of understanding placental development, structure and function Lawrence D. Longo and Lawrence P. Reynolds

Int. J. Dev. Biol. (2010) 54: 237-255

https://doi.org/10.1387/ijdb.082774II

Andrzej Krzysztof Tarkowski abroad, in photos and correspondence

Chris F. Graham

Int. J. Dev. Biol. (2008) 52: 171-178

https://doi.org/10.1387/ijdb.072443cg

Early mammalian embryo: my love. An interview with Andrzej K. Tarkowski Marek Maleszewski and Andrzej K. Tarkowski

Int. J. Dev. Biol. (2008) 52: 163-169

https://doi.org/10.1387/ijdb.072377mm

From embryo to ethics: a career in science and social responsibility. An interview with Anne McLaren

Brigid Hogan

Int. J. Dev. Biol. (2001) 45: 477-482

http://www.intjdevbiol.com/web/paper/11417887
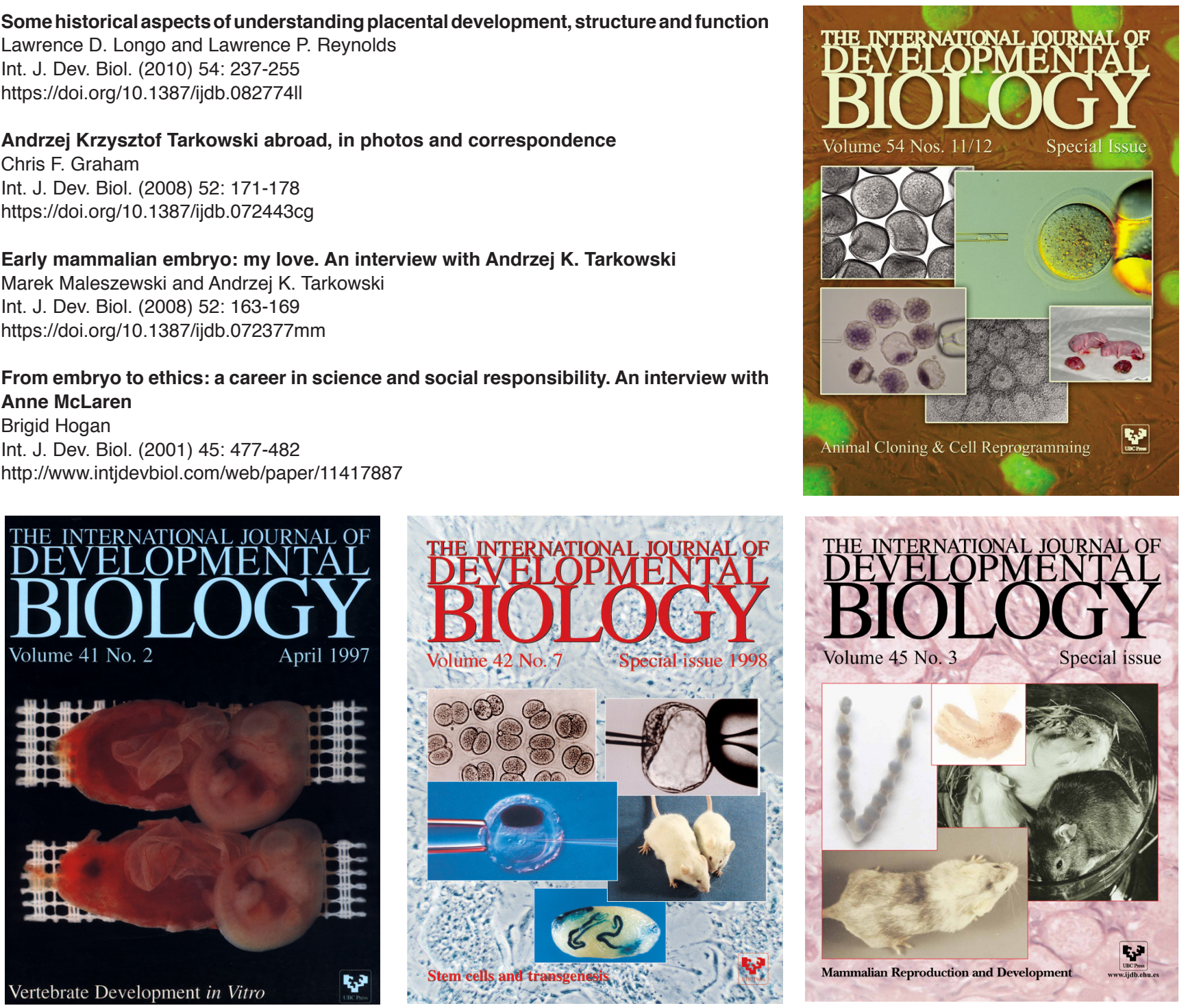